

\section{Argonne National Laboratory}

Argonne National Laboratory, with facilities in the states of Ilinois and Idaho, is owried by the United States govermment, and operatod by the University of Chicago under the provisions of a contract with the Department of Energy.

This document is a product of Argonne's Environmental Assosement and Information Sciences (EAIS) Division. For information on the division's sciontific and engineoring activities, contact:

Director, Environmental Assessment and Information Sciences Division

Argonne National Laboratory

Argonne, Illiriois $60439-4815$

Telephone (708) 262-3759

\section{Disclaimer}

This report was prepared as an account of work sponsoled by an agency of the United States Goveminent. Noither the United States Govemment nor any agency thereof, nor any of their employees, makes any warranty, express or implied, or assumes any legal liability or responsibility for the accuracy, completeness, or usefulness of any information, apparatuo, product, or process disclosed, or represents that its use would not iniringe privately owned rights. Reference herein to any specific commerdel product, process, or service by trade name, trademark, manufacturer, or otherwise, does not necesserily constitute or imply its entoreement, recommendation, or favoring by the United States Govemment or any agency thereot. The views and opiricns of authors expressed herein do not neressarily state or raflect those of the United States Govemment or any agency thereof.

Available to DOE and DOE sontractors from the Office of Sciontific and Technical Information, P.O. Box 62, Oak Ridga, 7N 37831; pricos available from (615) $576-8401$.

Available tis the public from the National Tochnictal Informaticn Senvice, U.S. Department of Commerce, 5285 Pant Royal Rood, Springfield, VA 22161. 


\section{Compendium of Selected References on Air Emissions; Health, Risk. and Valuation Research; and Environmental Externalities}

by C.B. Szpunar

International Coal and Technology Studies

Environmental Assessment and Information Sciences Division,

Argonne National Laboratory, 9700 South Cass Avenue, Argonne, Illinois 60439

July 1992

Work sponsored by U.S. Agency for International Develcpment 


\section{CONTENTS}

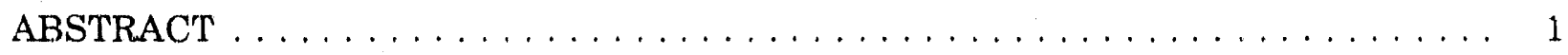

1. AIR EMISSIONS, AIR TOXICS, AND REGULATORY PIACTICES $\ldots \ldots \ldots \ldots$

1.1 Reviewed Reference Material . . . . . . . . . . . . . . . . . . . 1

1.2 Additional Reference Material . . . . . . . . . . . . . . . . . . . . . . 4

2 RISK ASSESSMENT - HEALTH AND EPIDEMIOLOGICAL EFFECTS . . . . . 5

2.1 Reviewed Reference Material . . . . . . . . . . . . . . . . E

2.2 Additional Reference Material . . . . . . . . . . . . . . . . . . 9

$3 \quad$ RISK ASSESSMENT - SOIL AND VEGETATION EFFECTS . . . . . . . . . . 11

3.1 Reviewed Reference Material . . . . . . . . . . . . . . . . . . 11

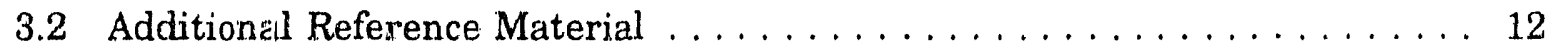

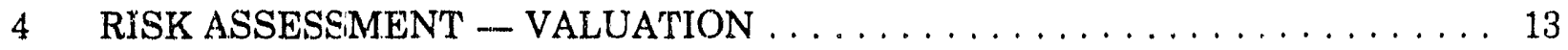

4.1 Reviewed Reference Material . . . . . . . . . . . . . . . . . 13

4.2 Additional Reference Material . . . . . . . . . . . . . . . 16

5 ENVIRONMENTAL EXTERNALITIES OR SOCIAL COSTS . . . . . . . . . . 19

5.1 Reviewed Reference Material . . . . . . . . . . . . . . . . . . . 19

5.2 Additional Reference Material . . . . . . . . . . . . . . . . . 22

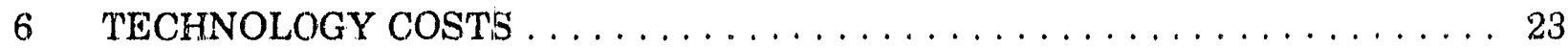

6.1 Reviewed Reference Material . . . . . . . . . . . . . . . . . . . 23

6.2 Additional Reference Material . . . . . . . . . . . . . . . . . 23

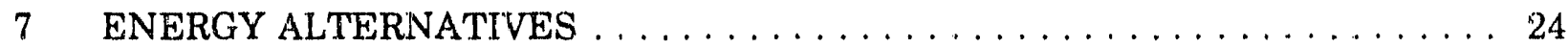

7.1 Reviewed Reference Material . . . . . . . . . . . . . . . . . . . 24

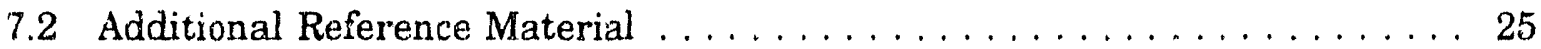




\title{
COMPENDIUM OF SELECTED REFERENCES ON AIR EMISSIONS; HEALTH, RISK, AND VALUATION RESEARCH; AND ENVIRONMENTAL EXTERNALITIES
}

by

C.B. Szpunar

\begin{abstract}
ABSTRAC'T
In preparing to develop a cost-benefit methodology that could be applied to potential projects abroad involving new coal-fired power plants that make use of U.S. clean coal technologies, the author reviewed a wide variety of reference sources. These arc listed in this publication. Before this review, the author had conducted a number of literature searches that identified source material in the newly rediscovered field of environmental externalities and related topics that might also be of value to other energy and environmental researchers. Thuse sources that appeared to be appropriate but that the author was unable to review are also listed in this document. Thus, this document serves as a comprehensive compendium of source material on these subjects, arranged alphabetically within categories.
\end{abstract}

\section{AIR EMISSIONS, AIR TOXICS, AND REGULATORY PRACTICES}

\subsection{REVIEWED REFERENCE MATEIRIAL.}

Bignoli, G., 1989, "Health and Environnental Impact of Chromium Released from Coal Ash," Journal of Coal Quality 8(3/4):72-81, July-Dec.

Bretz, E.A., 1991, "Reduce Transboundary Pollution with Clean Power from Coal," Power, international ed., pp. 29-33, March.

Brown, H.S., 1988, "Management of Carcinogenic Air Emissions: A Case Study of a Power Plant," Journal of Air Pollution Control Association 38(1):15-21, Jan.

Carras, J., G. Ross, B. Sawford, and R. Simpson, 1989, "Methods of Source-Receptor Modelling for Air Quality Applications," in Air Pollutants from Energy Inaustries: Scientrfic Basis of Standards and Research Needs, A.J. Jakeman (editor), proceedings of conference held in Canberra, New South Wales, Ausiralia, on May 19-20, 1987, published by Australian National University, Centre for Resource and Environmental Studies, Canberra, pp. 154-163. 
Doley, D., 1989, "The Roles of Research and Land Use Planning in the Establishment and Implementation of Air Quality Objectives," in Air Pollutants from Energy Industries: Scientific Basis of Standards and Research Needs, A.J. Jakeman (editor), proceedings of conference held in Canberra, New South Wales, Australia, on May 19-20, 1987, published by Australian National University, Centre for Resource and Environmental Studies, Canberro, pp. 146-153.

Electric Power Research Institute (EPRI), 1991, Analysis of Alternative $\mathrm{SO}_{2}$ Reduction Strategies: Final Report, report EPRI-EN/GS-7132, Palo Alto, Calif., Jan.

Environment Reporter, 1991, "Airborne Particulates Greatly Contribute to about 60,000 Deaths Annually, Study Says," 22(3):131-132, The Bureau of National Affairs, Inc., Washington, D.C., May 17.

Farrell, W.J., 1989, "Regulatory Practices in Victoria (Australia) for Energy-Based Pollutants," in Air Pollutants from Energy Industries: Scientific Basis of Standards and Research Needs, A.J. Jakeman (editor), proceedings of conference held in Canberra, New South Wales, Australia, on May-19-20, 1987, published by Australian National University, Centre for Resource and Environmental Studies, Canberra, pp. 76-81.

Fromholzer, D., 1983, "Decision Framework for Ambient Air Quality Standards," EPRI Journal, pp. 51-53, June.

Guthrie, A.C.M., 1989, "Regulatory Practices in New South Wales (Australia) and New Directions for Energy-Based Industries," in Air Pollutants from Energy Industries: Scientific Basis of Standards and Research Needs, A.J. Jakeman (editor), proceedings of conference held in Canberra, New South Wales, Australia, on May 19-20, 1987, puthlished by Australian National University, Centre for Resource and Environmental Studies, Canberra, pp. 82-85.

Hootman, H.A., and J.E. Vernet, 1991, Potential Impacts of Air Toxics Provisions of the Clean Air Act on Energy, report ANL/EAIS/TM-66, Argunne National Laboratory, Argonne, Ill., Nov.

Intarapravich, D., 1991, "Coal and the Environment in Thailand," presented at Coal and the Environment: Asia 2010 Conference, sponsored by East-West Center and U.S. Department of Energy, held in Honolulu, Hawaii, on July 11-12.

Jakeman, A.J. (editor), 1989, Air Pollutants from Energy Industries: Scientific Basis of Standards and Research Needs, proceedings of conference held in Canberra, New South Wales, Australia, on May 19-20, 1987, published by Australian National University, Centre for Resource and Environmental Studies, Canberra.

Kowalczyk, G.S., L.B. Gratt, and P.F. Ricci, 1987, "An Air Emission Risk Assessment for Benzo(a)pyrene and Arsenic from the Mt. Tom Power Plant," Journai of Air Pollution Control Association 37(4):361-369, April. 
Kowalczyk, G.S., L.B. Gratt, K.M. Conner, T.Y. Choi, and T.F. Wilson, 1988, "Emissions of Air Toxics from a Coal-Fired Power Plant: Evaluating the Trade-offs between Public Health Risks and Emission Control Costs," in proceedings of annual meeting of Air Pollution Control Association, held in Dallas, 'Texas, on June 19-24, published by Air Pollution Control Association, Pittsburgh, Penn.

Lefohn, A.S., and S.V. Krupa. 1988, "Acidic Precipitation: A Technical Amplification of NAPAP's Findings," Journal of Air Pollution Control Association 38(6):766-776, June.

Masuda, S., and R.E. Armington, 1984, "Environmental Concerns in Japan on the Use of Coal for Power Generation," in vol. 46 of proceedings of American Power Conference, held in Chicago, Ill., on April 24, published by Illinois Institute of Technology, Chicago, Ill., pp. 103-106.

Murray, F., G. Miles, and K. Bentley, 1989, "Research Needs for the Development of Ambient Air Quality Criteria to Protect Human Health, Vegetation, and Materials in Australia," in Air Pollutants from Energy Industries: Scientific Basis of Standards and Research Needs, A.J. Jakeman (editor), proceedings of conference held in Canberra, New South Wales, Australia, on May 19-20, 1987, published by Australian National University, Centre for Resource and Environmental Studies, Canberra, pp. 138-145.

Ottinger, R.L., 1990, "Regulatory Processes: Legal and Institutional Barriers," in proceedings of National Conference on Environmental Externalities, sponsored by National Association of Regulatory Utility Colnmissioners, held in Jackson Hole, Wyo., on Oct. 1-3.

Plueksawan, W., 1991, "Coal Use in the Electricity Sector of Thailand," presented at Coal and the Environment: Asia 2010 Conference, sponsored by East-West Center and U.S. Department of Energy, held in Honolulu, Hawaii, on July 11-12.

Rind, D., R. Goldberg, J. Hansen, C. Rosenzweig, and R. Ruedy, 1990, "Potential Environmental Transportation and the Likelihood of Future Drought," Journal of Geophysical Research, pp. 9983-1004, June 20.

Skea, J.F., and E.S. Rubin, 1988, "Optimization of Coal Beneficiation Plants for $\mathrm{SO}_{2}$ Emissions Control," Journal of Air Pollution Control Association 38(10):1281-1288, Oct.

Szpunar, C.B., E.C. Winegartner, C.J. Lin, and R.A. Nadkarni, 1980, The Fate of Trace Elemente in Coal Combustion, report Cn $2.24 \mathrm{KW} .80$, Exxon Research and Engineering, Baytown, Texas, Dec.

U.S. Environmental Protection Agency (EPA), 1991, National Air Quality and Emissions Trends Report, 1989, report EPA-450/4-91-003, Office of Air Quality, Planning and Standards, Technical Support Division, Research Triangle Park, N.C., Feb.

*Provides figures on power-generating capacity, emission standards and regulations, and chemical analyses of consumed coals. 
World Health Organization and United Nations Environment Programme, 1984, Urban Air Pollution: 1973-1980, World Health Organization, Geneva, Switzerland.

\subsection{ADDITIONAZ REFERENCE MATERIAL}

Alm, H., 1989, "Igelsta - A Modern Swedish District Heating Plant," Acid Magazine 8:27-28, Sept. 


\section{RISK ASSESSMENT - HEALTH AND EPIDEMIOLGAICAL EFFECTS}

\subsection{REVIEWED REFERENCE MATERIAL.}

Amaral, D., 1988, "Including Uncertainty in Assessments of Sulfur Oxide Health Risks," Journal of Air Pollution Control Association 38(4):399-405, April.

Bohal, L., P. Erban, J. Kadlec, V. Kraus, and V. Trcka, 1984, "Risks and Benefits of Energy Systems in Czechoslovakia," in Risks and Benefits of Energy Systems, proceedings of symposiurn sponsored by International Atomic Energy Agency (IAEA), United Nations Environment Programme (UNEP), and World Health Organization (WHO), held in Julich, West Germany, in April, published by IAEA, Vienna, Austria, pp. 553-565.

Department of Municipal Affairs and Environment, Fredericton, New Brunswick, Canada, 1988, Guidelines for an Environmental Impact Assessment of a $400 \mathrm{MW}$ Coal-Fired Generating Station, report NBMAE-89-04146, Nov. 28.

Dvorak, A.J., C.D. Brown, E.H. Dettman, R.R. Hinchman, J.D. Jastrow, F.C. Kornegay, C.R. LaFrance, B.G. Lewis, R.T. Lundy, R.D. Olsen, J.I. Parker, E.D. Pentecost, J.L. Saguinsin, and W.S. Vinikour, 1977, The Environmental Effects of Using Coal for Generating Electricity, report NUREG-0252, prepared by Argonne National Laboratory, Argonne, Ill., for the U.S. Nucleir Regulatory Commission, June.

Dvorak, A.J., B.G. Lewis, P.C. Chee, E.F. Dettman, R.F. Freeman, R.M. Goldstein, R.R. Hinchman, J.D. Jastrow, F.C. Kornegay, D.L. Mabes, P.A. Merry, E.D. Pentecost, J.C. Prioleau, L.F. Soholt, W.S. Vinikour, and E.W. Walbridge, 1978, Impacts of Coal-Fired Power Plants on Fish, Wildlife, and Their Habitats, report WS/OBS-78/29, U.S. Department of the Interior, March.

Easterling, J.B., R.J. Redmond, and E. Turner, 1990, "Social Issues and Challenges in the Disposal of Nuclear Waste," in vol. 2 of High Level Radioactive Waste Management, proceedings of International Topical Meeting sponsored by American Society of Civil Engineers and American Nuclear Society, held in Las Vegas, Nev., on April 8-12.

Erfani, G., and F.W. Bell, 1988, "The Impact of Migration on Air Quality Dose-Response Functions: A Case Study of Jacksonville, Florida," Journal of Air Pollution Control Association 38(7):917-920, July.

Ferris, B,G., Jr., 1978, "Health Effects of Exposure to Low Levels of Regulated Air Pollutants: A Critical Review," Journal of Air Pollution Control Association 28:482-496.

Freeman, A.M., 1979, "Approaches to Measure Public Good Demand," American Journal of Agricultural Economics 61(5):915-920. 
Freeman, A.M., 1979, The Benefits of Environmental Improvement: Theory and Practice, Resources for the Future, Inc., Washington, D.C., published by Johns Hopkins Press, Baltimore, Md.

Freeman, A.M., 1985, Methods for Assessing the Benefits of Environmental Programs, vol. 1 of Handbook of Natural Resource and Energy Economics, A.V. Kneese and J.L. Sweeney (editors), Elsevier Science Publishers, Amsterdam, The Netherlands, pp. 223-270.*

French, H., 1990, "You Are What You Breathe," Worldwatch 3(3):27-34, May-June.

Fritzsche, A.F., 1989, "The Health Risks of Energy Production," Risk Analysis 9(4):565-577.

Gotchy, R.L., 1983, "Health Risks from the Nuclear Fuel Cycle," in Health Risks of Energy Technologies, C.C. Travis and E.L. Etnier (editors), selected symposia series, American Association for the Advancement of Science, Washington, D.C., published by Westview Press, Inc., Boulder, Colo., pp. 35-75.

Graham, J.A., 1991, Direct Health Effects of Air Pollutants Associated with Acidic Precursor Emissions, NAPAP report SOS/T 22 in Acidic Deposition: State of Science and Technology, National Acid Precipitation Assessment Program, Washington, D.C., pp. 177-205.

Habegger, L.J., and A.H. Ozkaynaak, 1984, "Use of Health Effect Risk Estimates and Uncertainty in Formal Regulatory Proceedings: A Case Study Involving Atmospheric Particulates," in proceedings of 1984 annual meeting of Society of Risk Analysis, held in Knoxville, Tenn., in Oct.

Hamilton, L.D., 1982, "Comparing the Health and Environmental Hazards of Different Energy Systems," discussion paper presented at International Conference on Nuclear Power Experience sponsored by International Atomic Energy Agency, Vienna, Austria, held in Sept.

Hamilton, L.D., 1984, "Health and Environmental Risk of Energy Systems," in Risks and Benefits of Energy Systems, proceedings of symposium sponsored by International Atomic Energy Agency (IAEA), United Nations Environment Programme (UNEP), and World Health Organization (WHO), held in Julich, West Germany, in April, published by IAEA, Vienna, Austria, pp. 21-57.

Higgins, I.T.T., R.E. Waller, R.S. Chapman, and J.R. Goldsmith, 1978, "Health Effects of Exposure to Low Levels of Regulated Air Pollutants," Journal of Air Pollution Control Association 38:883-894.

Inhaber, H., 1979, "Risk with Energy from Conventional and Nonconventional Sources," Science 203:718-723.

"Mathematical techniques and models. 
Jacobson, B., 1984, "The Role of Air Pollution and Other Factors in Local Variations in General Mortality and Cancer Mortality," Archives of Environmental Health 39(4):306-313, Aug.

Jakeman, A.J. (editor), 1989, Air Pollutants from Energy Industries: Scientific Basis of Standards and Research Needs, proceedings of conference held in Canberra, New South Wales, Australia, on May 19-20, 1987, published by Australian National University, Centre for Resource and Environmental Studies, Canberra.

Krewski, D., E. Somers, and S.O. Winthrop, 1984, "Environmental Health Risk Assessment," in Risks and Benefits of Energy Systems, proceedings of symposium sponsored by International Atomic Energy Agency (IAEA), United Nations Environment Programme (UNEP), and World Health Organization (WHO), held in Julich, West Germany, in April, published by IAEA, Vienna, Austria, pp. 187-205.

Krewski, D., D. Murdoch, and J.R. Withey, 1989, "Recent Developments in Carcinogenic Risk Assessment," Health Physics 57, Supplement 1, pp. 313-325."

Lave, L.B., and E.P. Seskin, 1970, "Air Pollution and Human Health," Science 169(3947):723-733, Aug. 21.

Lave, L.B., and E.P. Stskin, 1977, Air Pollution and Human Health, Resources for the Future, Washington, D.C., published by Johns Hopkins Press, Baltimore, Md.

Morris, S.C., 1983, "Health Risks of Coal Energy Technology," in Health Risks of Energy Technologies, C.C. Travis and E.L. Etnier (editors), selected symposia series, American Association for the Advancement of Science, Washington, D.C., published by Westview Press, Inc., Boulder, Colo., pp. 77-139.

Morris, S.C., P.D. Moskowitz, W.A. Sevian, S. Silberstein, and L.D. Hamilton, 1979, "Coal Conversion Technologies: Some Health Environmental Effects," Science 206:654-662.

Munasinghe, M., et al., 1991, "Incorporation of Environmental and Health Impacts into Policy, Planning, and Decision Making for the Electricity Sector," paper 4 in Senior Expert Symposium on Electricity and the Environment: Key Issue Papers, proceedings of symposium held in Helsinki, Finland, in May, published by International Atomic Energy Agency, Vienna, Austria, pp. 143-184.

Niurray, F., 1989, "Dose-Response Information for the Effect of $\mathrm{SO}_{2}, \mathrm{NO}_{\mathrm{x}}$, and Particulates on Plants and Materials," in Air Pollutants from Energy Industries: Scientific Basis of Standards and Reseurch Needs, A.J. Jakeman (editor), proceedings of conference held in Canberra, New South Wales, Australia, on May 19-20, 1987, published by Australian National University, Centre for Resource and Environmental Studies, Canberra, pp. 21-31.

"Low-dose linearity and assessment. 
Murray, F., G. Miles, and K. Bentley, 1989, "Research Needs for the Development of Ambient Air Quality Criteria to Protect Human Health, Vegetation, and Materials in Australia," in Air Pollutants from Energy Industries: Scientific Basis of Standards and Research Needs, A.J. Jakeman (editor), proceedings of conference held in Canberra, New South Wales, Australia, on May 19-20, 1987, published by Australian National University, Centre for Resource and Environmental Studies, Canberra, pp. 138-145.

Myers, D.K., N.E. Gentner, and M.M. Werner, 1984, "Comparison of the Health Benefits and Health Risks of Energy Development," in Risks and Benefits of Energy Systems, proceedings of symposium sponsored by International Atomic Enersy Agency (IAEA), United Nations Environment Programme (UNEP), and World Health Organization (WHO), held in Julich, West Germany, in April, published by IAEA, Vienna, Austria, pp. 289-303.

National Acid Precipitation Assessment Program, 1987, Intrim Assessment, Washington, D.C.

National Acid Precipitation Assessment Program, 1990, Acidic Deposition: State of Science and Technology, reports SOS/T 1-27, Washington, D.C.

Nishiwaki, Y., H. Kawai, H, Morishima, T. Itakura, S. Kobayashi, T. Terano, and M. Sugeno, 1984, "Accidents and Human Factors," in Risks and' Benefits of Energy Systems, proceedings of symposium sponsored by international Atomic Energy Agency (IAEA), United Nations Environment Programme (UNEP), and World Health Organization (WHO), held in Julich, West Germany, in April, published by IAEA, Vienna, Austria, p. 441.

Organization for Economic Cooperation and Development (OECD), 1985, Environmental Effects of Electricity Generation, Paris, France.

Ottinger, R.L., D.R. Wooley, N.A. Robinson, D.R. Hodas, S.E. Babb, S.C. Buchanan, P.L. Chernick, E. Caverhill, A. Krupnick, and U. Fritsche, 1990, Environmental Costs of Electricity, D.R. Wolcott (editor), prepared by Pace University Center for Environmental Legal Studies for New York State Engineering Research \& Development Authority and U.S. Department of Energy, published $k_{;}$Oceana Publications, New York, N.Y.

Ozkaynak, H., G.D. Thurston, J.D. Spengler, et al., 1983-1985, Analysis of Health Effects Resulting from Population Exposures to Ambient Particulate Matter, Health and Environmental Effects Documents, Harvard University, Cambridge, Mass., Oct. 1983, Dec. 1983, and Sept. 1985.

Rowe, M. D., 1980, "Human Exposure to Sulfates from Coal-Fired Plants," Journal of Air Pollution Control Association, 30:682-684, June.

Soholt, L.F., R.W. Vocke, N.J. Beskid, W.K. Derickson, M.J. Knight, D.D. Ness, B. Siskind, and W.S. White, 1980, Handling of Combustion and Emission-Abatement Wastes from CoalFired Power Plants: Implications for Fish and Wildlife Resources, report FWS/OBS-80/33, U.S. Department of the Interior, Sept. 
Starr, C., 1969, "Social Benefit Versus Technological Risk," Science 165:1232-1238, Sept. 19."

Walsh, P.J., E.D. Copenhaver, E.E. Calle, C.S. Dudney, G.D. Griffin, A.P. Watson, J. Farthing, J.W. Pardue, C.C. Travis, J.P. Witherspoon, L. Sanathanan, and R. H. Busch, 1981, The Northeast Regional Environmental Impact Study: Reference Document for the Health Effects of Air Pollution, report ANL/ES.121, Argonne National Laboratory, Argonne, III., Nov.

Wyzga, R.E., 1982, "Air Follution and Mortality in London," EPRI Journal, pp. 46-47, May. Young, C., 1986, "Outdoor Air Pollution and Health," EPRI Journal, pp. 52-53, Dec.

\subsection{ADDITIONAL REFERENCE MATERLAL}

Brown, C. 1980, "Equalizing Differences in the Labor Market," Quarterly Journal of Economics 94:113-134, Feb.

Brown, G.E., Jr., 1975, The Costs and Effects of Chronic Exposure to Low-Level Pollutants in tiue Environment, report 49, presented by Subcommittee on the Eisvironment and the Atmosphere, Committee on Science and Technology, U.S. House of Representatives, to 94th Congress, Washington, D.C.

Cannon, J., 1990, The Health Costs of Air Pollution: A. Survey of Studies Published 1984.1989, American Lung Association, New York, N.Y.

Fritzsche, A.F., 1988, "Electricity Production, Health, and Environment," in Treatment and Storage of Radioactive Waste - An International Status Survey, proceedings of conference held in Zurich, Switzerland, on Oct. 18, pp. RA-1 through R4-44.

Heintz, H.T., A. Hershaft, and G. Horak, 1976, . Vational Damages of Air anci Water Pollution, report prepared by Enviro Control, Inc., Rockville, Md., for U.S. Environmental Protection Agency.

Horvath, L.G., Z. Techy, and L. Voeroess, 1986, "Risk Assessment Based on Case Studies for Reference Plantis of the Hungarian Energy System," in Assessing and Munaging Health and Environmental Risks from Energy and Other Complex Industrial Systems, proceedings of workshop sponsored by International Atomic Energy Agency (IAEA), United Nations Environment Programme (UNEP), and World Health Organization (WHO), held in Paris, France, on Oct. 13-17, pp. 387-400.

Moore and W.K. Viscusi, 1988, "The Quality of Adjusted Value of Life," Economic Enquiry, 26(369). ${ }^{\dagger}$

"Voluntary versus involuntary activities.

${ }^{\dagger}$ As cited in Ottinger et al. (1990), which is listed in Section 2.1. 
Smith, V.K., 1976, "The Measurement of Mortality and Air Pollution Relationships," Environment and Planning 8:149-1.162.

U.S. Atomic Energy Commission, 1974, Comparative Risk-Cost-Benefit Study of Alter native Sources of Electrical Energy, report WASH-1224, Washington, D.C., Dec.

Viscusi, W.K., 1979, Employment Hazards: An Investigation of Market Performance."

Viscusi, W.K., 1.983, Risk by Choice: Regulating Health and Safety in the Workplace."

Waddell, T.E., 1974, The Economic Damages of Air Pollution, U.S. Environmental Protection Agency, Office of Water Resources Research, May.

*As cited in Ottinger et al. (1990), which is listed in Section 2.1. 


\section{? RISK ASSESSMENT - SOIL AND VEGETATION EFFECTS}

\subsection{REVIEWED REFERENCE MATERIAL}

Doley, D., 1989, "The Roles of Research and Land Use Planning in the Establishment and Implementation of Air Quality Objectives," in Air Pollutants from Energy Industries: Scientific Basis of Standards and Research Needs, A.J. Jakeman (editor), proceedings of conference held in Canberra, New South Wales, Australia, on May 19-20, 1987, published by Australian National University, Centre for Resource and Environmental Studies, Canberra, pp. 146-153.

Dvorak, A.J., C.D. Đrown, E.H. Dettman, R.R. Hinchman, J.D. Jastrow, F.C. Kornegay, C.R. LaFrance, B.G. Lewis, R.T. Lundy, R.D. Olsen, J.I. Parker, S.D. Pentecost, J.L. Saguinsin, and W.S. Vinikour, 1977, The Environmental Effects of Using Coal for Generating Electricity, leport NUREG-0252, prepared by Argonne National Laboratory, Argonne, Ill., for U.S. Nuclear Regulatory Commission, June.

Dvorak, A.J., B.G. Lewis, P.C. Chee, E.H. Dettman, R.F. Freeman, R.M. Goldstein, R.R. Hinchman, J.D. Jastrow, F.C. Kornegay, D.L. Mabes, P.A. Merry, E.D. Pentecost, J.C. Prioleau, L.F. Soholt, W.S. Vinikour, and E.W. Walbridge, 1978, Impacts of Coal-Fired Power Plants on Fish, Wildlife, and Their Habitats, report FWS/OBS-78/29, U.S. Department of the Interior, March.

Moskowitz, P.D., E.A. Coveney, W.H. Medeiros, N.L. Oden; and H.C. Thode, Jr., 1984, "Agricultural Benefits of Controlling Atmospheric Emissions from Energy Sources," in Risks and Benefits of Energy Systems, proceedings of symposium sponsored by International Atomic Energy Agency (IAEA), United Nations Environment Programme (UNEP), and World Health Organization (WHO), held in Julich, West Germany, April, published by IAEA, Vienna, pp. 237.255.

Mulchi, C.L., P.J. Mastradone, and J.A. Armbruster, 1990, "Investigation of Trace Metal Concentrations in Crops and Soils near a Fossil-Fuel Power Plant in Maryland," Journal of Air and Waste Management Association 40(2):185-198, Feb.

Murray, F., G. Miles, and K. Bentley, 1989, "Research Needs for the Development of Ambient Air Quality Criteria to Protect Human Health, Vegetation, and Materials in Australia," in Air Pollutants from Energy Industries: Scientific Basis of Standards and Research Needs, A.J. Jakeman (editor), proceedings of conference he't in Canberra, New South Wales, Australia, on May 19-20, 1987, published by Australian National University, Centre for Resource and Environmental Studies, Canberra, pp. 138-145.

National Acid Precipitation Assessment Program, 1987, Intermim Assessment, Washington, D.C. 
National Acid Precipitation Assessment Program, 1990, Acidic Deposition: State of Science and Technology, reports SOS/T 1-27, Washington, D.C.

Ottinger, R.L., D.R. Wooley, N.A. Robinson, D.R. Hodas, S.E. Babb, S.C. Buchanan, P.L. Chemick, E. Caverhill, A. Krupnick, and U. Fritsche, 1990, Environmental Costs of Electricity, D.R. Wolcott (editor), prepared by Pace University Center for Environmental. Legal Studies for New York State Engineering Research \& Development Authority and U.S. Department of ¿nergy, published by Oceana Publications, New York, N.Y.

\subsection{ADDITIONAL REFEKENCE MATERIAL}

Gardner, D.W., 1988, Long-Term Changes in the Elemental Composition of Soil and Vegetation in the Vicinity of a Coal-Fired.Power Plant, University of Minnesota, Minneapolis, Minn.

Jukola-Sulonen, E.L., M. Korhonen, P. Noejd, and II. Raitio, 1989, Vitality of Forests Surrounding the Inkoo Cou'Fired Power Plant: A Follow-up Study 1988-89, report IVO-A-11/89 (ISBN 951-8928-8-2).

Krupnick, A., and R. Kopp, 1988, The Health and Agricultural Benefits of Reductions in Ambient Ozone in the United States, prepared for Office of Technology Assessment, contract H3-6820.0, June.

Thicke, F.E., 1988, Effect of Scrubber Sludge and Fly Ash on Soil Properties and Crop Growth, University of Illinois, Urbana-Champaign, Ill. 


\section{RISK ASSESSMENT - VALUATION}

\subsection{REVIEWED REFERENCE MATERIAL}

Black, S.C., and F. Niehaus, 1980, "Comparison of Risks and Benefits among Different Energy Systems," in Interactions of Energy and Climate, W. Bach, J. Pankrath, and J. Williams (editors), D. Reidel Publishing Co., Dordrecht, 'The Netherlands, pp. 421-436.

Chadwick, M.J., et al., 1991, "Comparative Environmental and Health Effects of Different Energy Systems for Electricity Generation," paper 3 in Senior Expert Symposium on Electricity and the Environment: Key Issue Papers, proceedings of symposium held in Helsinki, Finland, in May, published by International Atomic Energy Agency, Vienna, Austria, pp. 91-141.

El-Hinnawi, E.E., 1980, The Environmental Impacts of Production and Use of Energy: An Assessment, in vol. 1 of Natural Resources and the Environment monograph series, United Nations Environment Programme, published by Tycooly Press Ltd. and Irish Elsevier Printers Ltd., Nairobi, Kenya, Africa, Oct.

Finkel, A.M., and J.S. Evans, 1987, "Evaluating the Benefits of Uncertainty Reduction in Environmental Health Risk Management," Journal of Air Pollution Control Association 37(10):1164-1171, Oct.

Freeman, A.M., 1979, "Approaches to Measure Public Good Demand," American Journal of Agricultural Economics 61(5):915-920.

Freeman, A.M., 1979, The Benefits of Environmental Improvement: Theory and Practice, Resources for the Future, Inc., Washington, D.C., published by Johns Hopkins Press, Baltimore, Md.

Freeman, A.M., 1982, Air and Water Pollution. Control: A Benefit-Cost Assessment, John Wiley \& Sons, Inc., New York, N.Y.

Freeman, A.M., 1985, Methods for Assessing the Benefits of Environmental Programs, vol. 1 of Handbook of Natural Resource and Energy Economics, A.V. Kneese and J.L. Sweeney (editors), Elsevier Science Publishers, Amsterdarn, The Netherlands, pp. 223-270. ${ }^{\dagger}$

\footnotetext{
"This volume consolidates three studies into one text summarizing the state of knowledge at the end of the 1970s: (1) Environmental Impacts of Production, Transport, Processing, and Use of Fossil Fuels, Warsaw, April 1978; (2) Environmental Impacts of Nuclear Energy, Geneva, Switzerland, Nov. 1978, and Nairobi, Kenya, April 1979; and (3) Environmental Aspects of Renewable Sources of Energy, Bangkok, Thailand, Jan. 1980.

${ }^{\dagger}$ Mathematical techniques and models.
} 
Friedrich, R., E. Ruff, and A. Voss, 1984, "Costs and Effectiveness of Measures to Reduce $\mathrm{SO}_{2}$ Emissions: A Decision Support Analysis," in Risks and Benefits of Energy Systems, proceedings of symposium sponsored by International Atomic Energy Agency (IAEA), United Nations Environment Programme (UNEP), and World Health Organization (WHO), held in Julich, West Germany, April, published by IAEA, Vienna, Austria, pp. 367-377.

Hall, J.V., A.II. Winer, M.T. Kleinman, F ' Lurmann, V. Brajer, and S.D. Calome, 1992, "Valuing the Health Benefits of Clean Air," Science 255:812-817, Feb. 14.

Harris, C.C., and M.C. McGown, 1990, "The Propriety of Applying Economic Mcthode + 0 the silocation of Public Amenity Resources: Paradigms, Property Rights, and Progress,' in Economic Valuation of Natural Resources, R.L. Johnson and G.V. Johnson (editors), Westview Press, Inc., Boulder, Colo., pp. 51-65.

Holdren, J.P., K.B. Anderson, P.M. Deibler, P. H. Gleick, I.M. Mintzer, and C.P. Morris, 1983, "Health and Safety Impacts of Renewable, Geothermal, and Fusion Energy," in Health Risks of E'nergy Technologies, C.C. Travis and E.L. Etnier (editors), selectec symposia series, American Association for the Advancement of Science, Washington, D.C., published by Westview Press, Inc. Boulder, Colo., pp. 141-208.

Hubert, P., 1984, "Risk Indices in Comparative Risk. Assessment Studies," in Risks and Benefits of Energy Systems, proceedings of symposium sponsored by International Atomic Energy Agency (IAEA), United Nations Environment Programme (UNEP), and World Health Organization (WHO), held in Julich, West Germany, in April, published by LAEA, Vienna, Austria, pp. 305-319.

Joynt, R.C., 1989, "Costs and Benefits of Air Pollution Control in Electricity Generation in Victoria (Australia)," in Air Pollutants from Energy Industries: Scientific Basis of Standards and Research Needs, A.J. Jakeman (editor), proceedings of conference held in Camberra, New South Wales, Australia, on May 19-20, 1987, published by Australian National University, Centre for Resource and Environmental Studies, Canberra, pp. 86-96.

Kallenbach, A., E. Thone, A. Voss, 1988, "Comparative Risks of Different Electricity Generating Systems," in Envrisk 66, proceedings of international workshop held in Como, Italy.

Kim, E.-A., and W.-H. Hong, 1989, "Environmental Assessment on Coal-Fired Power Plant and Its Possible Socio-Economic Impacts to the Society at the National and Local Level," paper 2.2.13 in World Energy Conference, 14th Congress: Energy for Tomorrow, proceedings of conference held in Montreal, Quebec, Canada, on Sept. 17-22, published by Organizing Committee of 14th WEC Congress, Quebec, Canada, pp. 1-21.

\footnotetext{
*For occupational effects, fatalities, and lost work days.
} 
Kowalczyk, G.S., L.B. Gratt, K.M. Conner, T.Y. Choi, and T.F. Wilson, 1988, "Emissions of Air Toxics from a Coal-Fired Power Plant. Evaluating the Trade-offs between Public Health Risks and Emission Control Costs," in proceedings of annual meeting of Air Pollution Control Association, held in Dallas, Texas, on June 19-24, published by Air Pollution Control Association, Pittsburgh, Penn.

Lave, L.B., and E.P. Seskin, 1970, "Air Pollution and Human Health," Science 169(3947):723-733, Aug. 21.

Lave, L.B., and E.P. Seskin, 1977, Air Pollution and Human Health, Resources for the Future, Washington, D.C., published by Johns Hopkins :ress, Baltimore, Md.

Lochard, J., and P. Pages, 1984, "Cost Effectiveness Analysis of Risk Reduction at Nuclear Power Plants: What Have We Learned from Experience?" in Risks and Benefits of Energy Systems, proceedings of symposium sponsored by International Atomic Energy Agency (IAEA), United Nations Environment Programme (UNEP), and World Hea'th Organization (WHO), held in Julich, West Germany, in April, published by IAEA, Vienna, Austria, pp. 339-352.

Loehman, E.T., S.V. Berg, A.A. Arroyo, R.A. Hedinger, J.M. Schwartz, M.E. Shaw, R.W. Fahien, V.H. De, R.P. Fishe, D.E. Rio, W.F. Rossley, and A.E.S. Green, 1979, "Distributional Analysis of Regional Benefits and Cest of Air Quality Control," Journal of Environmental Economics and Management 6(3):222-243.

Myers, D.K., N.E. Gentner, and M.M. Werner, 1984, "Comparison of the Health Benefits and Health Risks of Energy Development," in Risks and Benefits of Energy Systems, proceedings of symposium sponsored by International Atomic Energy Agency (IAEA), United Nations Environment Programme (UNEP), and World Heaith Organization (WHO), held in Julich, West Germany, in April, published by IAEA, Vienna, Austria, pp. 289-303.

Nordhaus, W.D., 1991, "To Slow or Not to Slow: The Economics of the Greenhouse Effect," Economic Journal 101:920-937, July.

Ottinger, R.L., D.R. Wooley, N.A. Robinson, D.R. Hodas, S.E. Babb, S.C. Buchanan, P.L. Chernick, E. Caverhill, A. Krupnick, and U. Fritsche, 1990, Environmental Costs of Electricity, D.R. Wolcott (editor), prepared by Pace University Center for Environmental Legal Studies for New York State Engineering Research \& Development Authority and U.S. Department of Energy, published by Oceana Publications, New York, N.Y.

Peterson, D.C., D.M. Violette, R.D. Rowe, and L.G. Chestnut, 1988, Benefits of Environmental Controls: Measures, Methods, and Applications, report EA-6030, Electric Power Research Institute (EPRI), Palo Alto, Calif., Oct. 
Schulze, W.D., D.S. Brookshire, and R.C. d'Arge, 1983, "Economic Valuation of the Risks and Impacts of Energy Development," in Health Risks of Energy Technologies, C.C. Travis and E.L. Etnier (editors), selected symposia series, American Association for the Advancement of Science, Washington, IJ.C, published by Westview Press, Inc., Boulder, Colo., pp. 229-278.

Sigma Research, 1977, Proceedings of a Workshop on the Measure of Intangible Environmental Impacts, report EA-405-SR, Electric Power Research Institute (EPRI), Palo Alto, Calif.

Starr, C., 1969, "Social Benefit Versus Technological Risk," Science 165:1232-1238, Sept. 19."

Viscusi, W.K., 1989, "Toward a Diminished Role for Tort Liability: Social Insurance, Government Regulation, and Contemporary Risks to Health and Safety," Yale Journal on Regulation 6(1), winter.

U.S. Department of Energy, 1986, BPA Evaluation of Generic Environmental Costs \& Benefits Studies, Bonneville Power Administration, Portland, Ore.

World Resources Institute and International Institute for Environment and Development in collaboration with United Nations Environment Programme, 1988, World Resources 1988. 1989: An Assessment of the Resource Base that Supports the Global Economy, Basic Books, Inc., New York, N.Y.

\subsection{ADDITIONAL REFERENCE MATERIAL}

Brown, G.E., Jr., 1975, The Costs and Effects of Chronic Exposure to Low-Level Pollutants in the Environment, report 49, presented by Subcommittee on the Environment and the Atmosphere, Committee on Science and Technology, U.S. House of Representatives, to 94th Congress, Washington, D.C.

Cannon, J., 1990, The Health Cosis of Air Pollution: A Survey of Studies Pubiished 1984-1989, American Lung Association, New York, N.Y.

Crocker, T.D., W.D. Schulze, S. Ben-David, and A.V. Kneese, 1979, "Methods Development for Assessing Air Pollution Control Benefits," in vol. 1 of Experiments in the Economics of Epidemiology, U.S. Environmental Protection Agency, Washington, D.C.

Daly, H., 1990, "The Ecological Economics of Sustainability," presented at conference sponsored by International Society for Ecological Economists, held on May 21-23, published by The World Bank, Washington, D.C.

\footnotetext{
*Voluntary versus involuntary activities.
} 
Hall, J., 1989, Economic Assessment of the Health Benefits from Improvements in Air Quality in the South Coast Air Basin, report prepared for South Coast Air Quality Management District, published by California State University, Fullerton Foundation, Fullerton, Calif,, June.

Harrison, D., and A.R. Nichols, 1990, Benefits of 1989 Air Quality Management Plan for South Coast Air Basin: A Reassessment, prepared by Arthur D. Little, Cambridge, Mass., for California Council for Environmental and Economic Balance, Feb."

Heintz, H.T., A. Hershaft, and G. Horak, 1976, National Damages of Air and Water Pollution, report prepared by Enviro Control Inc., Rockville, Md., for U.S. Environmental Protection Agency.

Krawiec, F., 1980, Economic Measurement of Environmental Damages, Solar Energy Research Institute, Golden, Colo., May.

Liu, B., and E.S. Yu, 1976, Physical and Economic Damage Functions for Air Pollutants by Receptor, report prepared for U.S. Environmental Protection Agency, Corvallis, Ore.

Moore and W.K. Viscusi, 1988, "Doubling the Estimated Value of Life: The Implications of New Occupational Fatality Data," Journal of Policy Analysis and Management 7. ${ }^{\dagger}$

Olson, C., 1981, "An Analysis of Wage Differentials Received by Workers on Dangerous Jobs," The Journal of Human Resources 16(2).

Shuman, M., and R. Cavanagh, 1982, A Model Conservation and Electric Power Plan for the Pacific Northwest, App. A., Northwest Conservation Act Coalition, Seattle, Wash., Nov.

Small, K.A., 1977, "Estimating Air Pollution Costs of Transport Modes," Journal of Economics 11(2)109-132, May.

Smith, V.K., 1976, "The Measurement of Mortality and Air Pollution Relationships," Environment and Planning 8:149-162.

Thaler, R., and S. Rosen, 1976, "The Value of Saving a Life: Evidence from the Labor Market," in Household Production and Consumption, N. Terkeckyj (editor), Columbia University Press, New York, N.Y.

Thibodeau, L.A., et al., 1980, "Air Pollution and Human Health: A Review and Reanalysis," Environmental Health Perspectives 34:165-181, Feb.

\footnotetext{
${ }^{*}$ Morbidity estimate for $\mathrm{NO}_{\mathrm{x}}$.

${ }^{\dagger}$ As cited in Ottinger et al. (1990), which is listed in Section 4.1.
} 
Viren, J.R., 1978, Cross-Sectional Estimates of Mortality Due to Fossil Fuel Pollutants: A Case for Spurious Association, report prepared for U.S. Department of Energy, Washington, D.C.

Viscusi, W.K., 1984, The Valuation of Risks to Life and Health: Guidelines for Policy Analysis, paper prepared for National Science Foundation."

\footnotetext{
*As cited in Ottinger et al. (1990), which is listed in Section 4.1.
} 


\section{ENVIRONMENTAL EXTERNALITIES OR SOCIAL COSTS}

\subsection{REVIEWED REFERENCE MATERIAL}

Bernow, S., B. Biewald, and D. Marron, 1991, "Fuel-Cost Dispatch: Incorporating Environmental Externalities in Electric System Operation," Electricity Journal 4(2):2)-33, March.

Boras, K., J. Finnell, T. Kennedy, K. DeGroat, 1990, Considering Social Costs in Utility Decision Making: Alternative Approaches and Implementation, report prepared by Meridian Corp., Alexandria, Va., for Pacific Gas and Electric Company, San Ramon, Calif., Nov. 1.

Browne, G., 1991, "A Utility View of Externalities: Evaluation, Not Revolution," Electricity Journal 4(2):34-39, March.

Buchanan, S.C., 1990, "Estimating Environmental Costs of Energy Resources," Electricity Journal 3(6):36-41, July.

Chernick, P., and E. Caverhill, 1991, "Methods of Valuing Environmental Externalities," Electricity Journal 4(2):46-53, March.

Cohen, S.D., J.H. Eto, C.A. Goldman, J. Beldoch, and G. Crandall, 1990, "Environmental Externalities: What State Regulators Are Doing," Electricity Journal 3(6):24, July.

Easterling, J.B., R.J. Redmond, and E. Turner, 1990, "Social Issues and Challenges in the Disposal of Nuclear Waste," in vol. 2 of High Level Radioactive Waste Management, proceedings of International Topical Meeting sponsored by American Society of Civil Engineers and American Nuclear Society, held in Las Vegas, Nev., on April 8-12.

Electric Power Alert, 1992, "To Promote the Use of Coal, National Council Calls for Pro-Coal Campaign, Approves Externalities Study," 11(2):15, McGraw-Hill Book Co., Inc., New York, N.Y., Feb. 5.

Electric Power Alert, 1992, "Environmental Adders: Advisory Group Study Targets Impact of State Externality Rules on Coal," 11(3):17, McGraw-Hill Book Co., Inc., New York, N.Y., Feb. 19.

Electric Power Alert, 1992, "Environmental Adders: Industrial Users Denounce Externalities in Acid Rain Program," 11(5):9, McGraw-Hill Book Co., Inc., New York, N.Y., March 4.

Electric Power Research Institute (EPRI), 1991, Environmental Externalities: An Overview of Theory and Practice, report EPRI-CU/EN-7294, Palo Alto, Calif., May. 
Finnell, J., T.G. Kennedy, and T.E. Monk, 1990, Ealuating Externalities Related to the Energy Sector, report prepared by Meridian Corp., Alexandria, Va., for PT Resource Development Consultants (REDECON) as attachment to Energy Pricing and Policy Study (EPPS), Aug. 1.

Freeman, A.M., 1979, "Approaches to Measure Public Good Demand," American Journal of Agricultural Economics 61(5):915-920.

Freeman, A.M., 1979, The Benefits of Environmental Iinurovement: Theory and Practice, Resources for the Future, Inc., Washington, D.C., published by Johns Hopkins Press, Baltimore, Md.

Freeman, A.M., 1982, Air and Water Pollution Control: A Benefit-Cost Assessment, John Wiley \& Sons, Inc., New York, N.Y.

Freeman, A.M., 1985, Methods for Assessing the Benefils of Environmental Programs, vol. 1 of Handbook of Natural Resource and Energy Economics, A.V. Kneese and J.L. Sweeney (editors), Elsevier Science Publishers. Amsterdam, The Netherlands, pp. 223-270.*

Fromholzer, D., and R. Richels, 1983, Acidic Deposition: Decision Framework, report EA2540, vol. 3, Electric Power Research Institute (EPRI), Palo Alto, Calif., Dec. ${ }^{\dagger}$

Fromholzer, D., and R. Richels, 1984, "Acidic Deposition Decision Framework: State-Level Application (ADEPT model)," EPRI Journal, pp. 50-53, March.

Fry, E.H., 1991, personal communication, Massachusetts Department of Public Utilities, Boston, Mass., Nov.

Grahame, T.J., 1991, testimony D.P.U. 91-131 before the Commonwealth of Massachusetts Department of Public Utilities (D.P.U.), Boston, Mass., Oct. 4 and Dec. 12, and responses to seventh set of data requests. ${ }^{\ddagger}$

Haites, E.F., 1990, "Introduction to the Use of Social Costs in Utility Planning and Regulation," in proceedings of National Conference on Environmental Externalities sponsured by National Association of Regulatory Utility Commissioners, held in Jackson Hole, Wyo., on Oct. 1-3.

\footnotetext{
*Mathematical techniques and models.

${ }^{\dagger}$ Minnesota cost-benefit analysis.

FThis document/testimony explains the U.S. Department of Energy (DOE) perspective on environmental externality values, mentions a joint U.S. DOE/Commission of the European Communities fuel-cycle study (expected summer 1992), and presents externality values used by specific state public utility commissions.
} 
Hohmeyer, O., 1988, Social Costs of Energy Consumption - Externalities of Electricity Generation in the Federal Republic of Germany, Springer-Verlag, Berlin, West Germany.

Idso, S.B. (Arizona State University, Tempe, Ariz.), 1991, "Environmental Externalities of $\mathrm{CO}_{2}$ Emissions: Unproven Costs vs. Established Benefits," unpublished paper prepared for Western Fuels Association, Calif.*

Jakeman, A.J. (editor), 1989, Air Pollutants from Energy Industries: Scientific Basis of Standards and Research Needs, proceedings of conference held in Canberra, New South Wales, Australia, on May 19-20, 1987, published by Australian National University, Centre for Resource and Environmental Studies, Canberra.

Jones, D.E., and P. Hanser, 1991, Environmental Externalities: An Overview of Theory and Practice, report CU/EN-7294, Electric Power Research Institute (EPRI), Palo Alto, Calif., May.

Joskow, P.L., 1991, "Dealing with Environmental Externalities: Let's Do It Right!" paper presented at Harvard No: theast Electric Utility Executive Confercnce, held in Killington, Vt., on Oct. 17-18.

Joynt, R.C., 1989, "Costs and Benefits of Air Pollution Control in Electricity Generation in Victoria (Australia)," in Air Pollutants from Energy Industries: Scientific Basis of Standards and Resear.h Needs, A.J. Jakeman (editor), proceedings of conference held in Canberra, New South Wales, Australia, on May 19-20, 1987, published by Australian National University, Centre for Resource and Environmental Studies, Canberra, pp. 86-96.

Lave, L.B., 1991, testimony D.P.U. 91-131 before the Commonwealth of Massachusetts Department of Public Utilities (D.P.U.), Boston, Mass.

Moskovitz, D.H., 1990, "Why We Need An Environmental Trust Fund," in proceedings of National Conference on Environmental Externalities sponsored by National Association of Regulatory Utility Commissioners, held in Jackson Hole, Wyo., on Oct. 1-3.

Ottinger, R.L., 1990, "Getting at the True Cost of Electric-Power," Electricity Journal 3(6):14-23, July.

Ottinger, R.L., D.R. Wooley, N.A. Robinson, D.R. Hodas, S.E. Babb, S.C. Buchanan, P.L. Chernick, E. Caverhill, A. Krupnick, and U. Fritsche, 1990, Environmental Costs of Electricity, D.R. Wolcott (editor), prepared by Pace University Center for Environmental Legal Studies for New York State Engineering Research \& Development Authority and U.S. Department of Energy, published by Oceana Publications, New York, N.Y.

${ }^{*}$ With 52 references, 26 pages. 
Peterson, D.C., D.M. Violette, R.D. Rowe, and L.G. Chestnut, 1988, Benefits of Environmental Controls: Measures, Methods, and Applications, report EA-6030, Electric Power Research Institute (EPRI), Palo Alto, Calif., Oct.

Stalon, C.G., 1990, "Lessons from Economics for Regulators Desiring to Reduce Harmful Environmental Externalities Produced by Utilities," in proceedings of National Conference on Environmental Externalities sponsored by National Association of Regulatory Utility Commissioners, held in Jackson Hole, Wyo., on Oct. 1-3.

Wiel, S., 1991, "The New Environmental Accounting: A Status Report," Electricity Journal 4(9):46-54, Nov.

Wolfe, A.K., 1990, "Incorporating Social Concerns in Environmental Impact Assessments," CONF-9003123-1 (conference paper available on microfiche only), Oak Ridge National Laboratory, Oak Ridge, Tenn., March.

\subsection{ADDITIONAL REFERENCE MATERIAL}

Chernick, P., and E. Caverhill, 1989, The Valuation of Externalities from Energy Production, Delivery, and Use, prepared by Resource Insight, Boston, Mass., for Boston Gas Company, Boston, Mass., Dec. 22.

ECO Northwest, 1984, Economic Analysis of the Environmental Effects of a CombustionT'urbine Generating Station at Fredrickson Industrial Park, Pierce County, Washington: Final Report, prepared by ECO Northwest, Portland, Ore., for Bonneville Power Administration, Portland, Ore., March 28.

ECO Northwest, 1987, Generic Coal Study: Quantification and Valuation of Environmental Impacts, prepared by ECO Northwest, Portland, Ore., for Bonneville Power Administration, Portland, Ore.

Gregory, R., R. Mendelsohn, and P. Slonic, 1987, Review of Uncertainty and Risk in BPASponsored Analyses of Energy Resources, Bonneville Power Administration, Portland, Ore., Nov. 18.

Shuman, M., and R. Cavanagh, 1982, A Model Conservation and Electric Power Plan for the Pacific Northwest, App. A., Northwest Conservation Act Coalition, Seattle, Wash., Nov. 


\section{TECHNOLOGY COSTS}

\subsection{REVIEWED REFERENCE MATERIAL}

Baasel, W.D., 1988, "Capital and Operating Costs of Wet Scrubbers," Journal of Air Pollution Control Association 38(3)327-332, June.

Jones, J.W., T.E. Emmel, B.A. Laseke, 1988, "Performance/Cost Estimates for Retrofitting Control Technologies at 12 Coal-Fired Powar Plants," Journal of Air Pollution Control Association 38(6):852-856, June.

Nemerow, N.L., T.N. Veziroglu, and A.T. Tekindur, 1989, "Economic Rationale for Environmental Pollution Control," in vols. 1 and 2 of proceedings of 9th Miami International Congress on Energy and Environment, held in Miami Beach, Fla., on Dec. 11-13, published by University of Miami, College of Engineering, Coral Gables, Fla.

Schaerer, B., and N. Haug, 1990, "Bilanz der Grossfeuerungsanlagen-Verordnung (Balance of the Ordinance on Large Cornbustion Plants: Measures, Cost, and Effectiveness)," Staub. Reinhaltung der Luft 50(4):139-144, April.

Seong, K.B., and B.W. Lee, 1989, "Economic Assessment of Coal-Fired and Nuclear Power Generation in the Year 2000 - Equal Health Hazard Risk Basis, Journal of the Korean Nuclear Society 21(3):171-185, Sept.

\subsection{ADDITIONAL REFERENCE MATERIAL}

Electric Power Development Co., 1988, EPDC in Soedertaelje - Clean Coal Technologies, proceedings of conference sponsored by EPDC. Tokyo, Japan, held in Soedertaelje, Sweden, on Oct. 28.

Organization for Economic Cooperation and Development (OECD), 1987, Energy and Cleaner Air: Costs of Reducing Emissions, Paris, France."

Smith, S.R., 1988, "Experience with Combined Coal Cleaning and Flue Gas Desulfurization," in Reducing Electricity Generaticn Costs by Improving Coal Quality, proceedings of conference held in Indiana, Penn., on Nov. 5, 1986, pp. 12.1-12.8, May.

\footnotetext{
"As cited in Finnell et al. (1990), which is listed in Section 5.1.
} 


\section{ENERGY ALTERNATIVES}

\subsection{REVIEWED REFERENCE MATERIAL}

Foley, L.O., and A.D. Lee, 1990, "Scratching the Surface of the New Planning: A Selective Look," Electricity Journal 3(6):48, July.

Fraser, W.L., 1989, "Low-Cost Environmental Control Technologies for Coal Utilization," paper 2.3.4 in World Energy Conference, 14th Congress: Energy for Tomorrow, proceedings of conference held in Montreal, Quebec, Canada, on Sept. 17-22, published by Organizing Committee of 14th WEC Congress, Quebec, Canada, pp. 1-13.

Garribba, S., 1990, "Technology and Environment: Emission Controls for Stationary Energy Sources: Overview of Experience of IEA Member Countries," in Seminar on Energy in East and West: The Polish Case, proceedings of symposium sponsored by International Energy Agency (IEA), Government of Denmark, and Government of Poland, held in Copenhagen, Denmark, on April 2-4, published by Organization for Economic Cooperation and Development (OECD), Paris, France, pp. 463-483.

Garribba, S., et al., 1991, "Energy Sources and Technologies for Electricity Generation," paper 2 in Senior Expert Symposium on Electricity and the Environiment: Key Issue Papers, proceedings of conference held in Helsinki, Finland, in May, published by International Atomic Energy Agency, Vienna, Austria, pp. 43-90.

Jalal, A.I., A.M. Khan, and S.B. Khan, 1984, "Alternative Energy Supply Strategies for Pakistan and Their Economic Implications," in Risks and Benefits of Energy Systems, proceedings of symposium sponsored by International Atomic Energy Agency (IAEA), United Nations Environment Programme (UNEP), and World Health Organization (WHO), held in Julich, West Germany, in April, published by IAEA, Vienna, Austria, pp. 619*631.

Kemper, R., 1990, "Cogeneration and District Heating as Viewed by the Federal Government (West Germany)," in Seminar of Energy in East and West: The Polish Case, proceedings of symposium sponsored by International Energy Agency (IEA), Government of Denmark, and Government of Poland, held in Copenhagen, Denmark, in April, published by Organization for Economic Conperation and Development (OECD), Paris, France, pp. 232-247.

Ksiezopolski, J., 1990, "Present State and Projected Development of the Polish Electric Power System," in Seminar of Energy in East and West: The Polish Case, proceedings of symposium sponsored by International Energy Agency (IEA), Government of Denmark, and Government of Poland, held in Copenhagen, Denmark, in April, published by Organization for Economic Cooperation and Development (OECD), Paris, France, pp. 106-121.

Leone, M., 1991, "Cleaning the Air the Market-Based Way," Power 134(12):9, Dec. 
Lipka, L., 1990, "District Heating Systems in Poland," in Seminar of Energy in East and West: The Polish Case, proceedings of symposium sponsored by International Energy Agency (IEA), Government of Denmark, and Government of Poland, held in Copenhagen, Denmark, in April, published by Organization for Economic Cooperation and Development (OECD), Paris, France, pp. 228-231.

Mortensen, H.C., 1990, "Cumbined Heat and Power, including District Heating: A Utility Point of View," in Seminar of Energy in East and West: The Polish Case, proceedings of symposium sponsored by International Energy Agency (IEA), Government of Denmark, and Government of Poland, held in Copenhagen, Denmark, in April, published by Organization for Economic Cooperation and Development (OECD), Paris, France, pp. 249-260.

Pasierb, S., 1990, "Rational Use of Energy in Poland: Present State and Future Tendencies," in Seminar of Energy in East and West: The Polish Case, proceedings of symposium sponsored by International Energy Agency (IEA), Government of Denmark, and Government of Poland, held in Copenhagen, Denmark, is April, published by Organization for Economic Cooperation and Development (OECD), Paris, France, pp. 493-506.

Schemenau, W., and J. Schoedel, 1990, "Coal-Fired Power Plants: The Next Generation," presented at ASME/IEEE Joint Power Generation Conference, held in Boston, Mass., on Oct. 21-25, published by American Society of Mechanical Engineers, New York, N.Y.

United Nations Environment Programme (UNEP), 1981, Environmental Impacts of Production and $U$ se of Energy, Nairobi, Kenya.

\subsection{ADDITIONAL REFERENCE MATERIAL}

Bland, P.F., 1986, "Problems of P.ice and Transportation: Two Proposals to Encourage Competition from Alternative Energy Resources," Harvard Law Review 10(2).

International Coal Development Institute, 1988, Why Choose Coal: The Case for Coal in Power Generation, London, United Kingdom.

Nakabayashi, Y., 1988, "Environmental Control Technologies Update for Coal-Fired Power Station," in EPDC in Soedertaelje - Clean Coal Technologies, proceedings of conference sponsored by Electric Power Development Co., Tokyo, Japan, held in Soedertaelje, Sweden, on Oct. 28, pp. 1-36.

Takahashi, M., 1988, "EPDC's R\&D Program for Clean Use of Coal," in EPDC in Soedertaelje - Clean Coal Technologies, proceedings of conference sponsored by Electric Power Development Co., Tokyo, Japan, held in Soedertaelje, Sweden, on Oct. 28, pp. 1-44. 

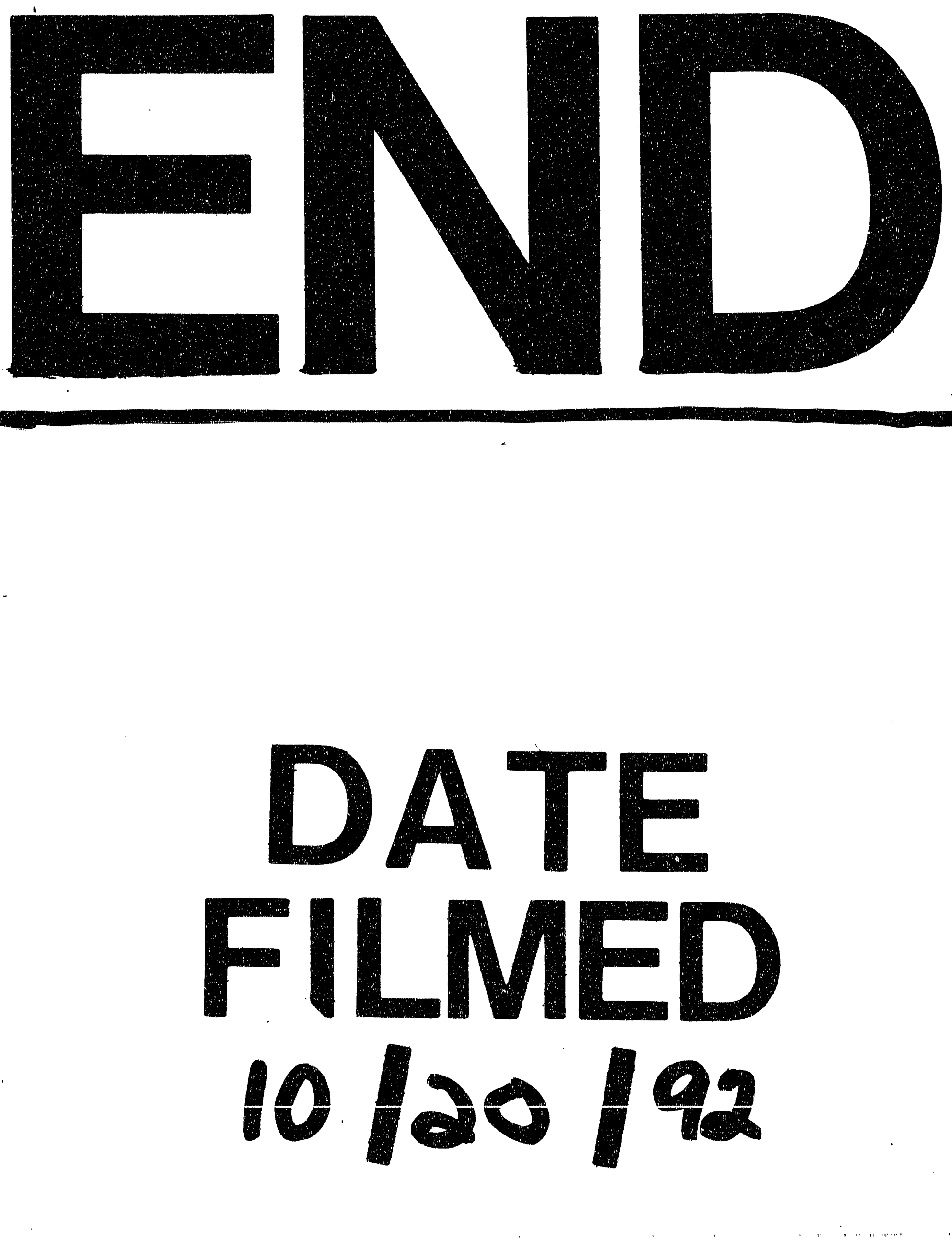
